\title{
Invasion of Plant Tissue in the Rumen by the Flagellate Neocallimastix frontalis
}

\author{
By C. G. OR PIN \\ Department of Biochemistry, Agricultural Research Council, \\ Institute of Animal Physiology, Babraham, Cambridge CB2 $4 A T$
}

(Received I5 July 1976)

SUMMARY

The flagellate stage of the rumen phycomycete Neocallimastix frontalis invades and germinates on plant material in the rumen and in vitro, preferentially invading the lemmas, paleas, awns and flower bracts in members of the plant family Gramineae, and flower bracts in certain of the Papilionaceae. The principal sites of invasion were the stomata and damaged tissue, through which penetration of the plant tissue by the rhizoid of the germinating cell occurred. Subsequent growth of the vegetative stage occurred with the uptake of ${ }^{14} \mathrm{C}$ from ${ }^{14} \mathrm{C}$-labelled plant tissue. Host diets rich in seed-head material normally supported higher population densities of $N$. frontalis in the rumen even though the dry matter digestibilities of these diets were lower.

\section{INTRODUCTION}

The life-history of the rumen organism Neocallimastix frontalis consists of a cycle alternating between two phases - a motile, flagellated phase and a non-motile, vegetative and reproductive phase (Orpin, 1975). The reproductive phase shows a morphological resemblance to that of certain of the aquatic phycomycetes, and contains chitin in the cell walls (Orpin, 1977). Although the flagellate possesses up to I4 flagella compared to a maximum of two recorded by Sparrow (1960) for members of the phycomycetes, it is probably a member of this group.

The flagellate stage of $N$. frontalis has been recognized for many years as a normal rumen inhabitant (Braune, 19I3; Das Gupta, 1935; Eadie, 1962); large population density fluctuations of the flagellate occur over the feeding period of the host animal (Warner, I966; Orpin, 1974). These are caused by the stimulation of reproductive bodies (sporangia) borne on the vegetative phase of $N$. frontalis to differentiate internally and liberate the flagellates in response to a component in the diet of the host animal (Orpin, 1975).

Although the rumen contains an abundance of plant particles (Orpin, 1975), it is only now that the vegetative phase of $N$. frontalis has been seen to invade and grow upon selected tissues of several plants within the rumen; the affinity of $N$. frontalis for these tissues is reported here.

\section{METHODS}

The sheep, defaunation procedure and counting techniques, except those described below, were those used by Orpin (1975).

Establishment of $N$. frontalis as the sole phycomycete in the rumen. Neocallimastix frontalis, Sphaeromonas communis and Piromonas communis were removed completely from the rumen of a defaunated sheep using actidione. Rumen fluid $(200 \mathrm{ml})$ was removed $2 \mathrm{~h}$ 
after feeding and actidione dissolved in water was added to give a final concentration in the rumen of $10 \mu \mathrm{g} \mathrm{ml}^{-1}$. The treated fluid was then returned to the rumen. After $18 \mathrm{~h}$ the rumen fluid was sampled again; no phycomycete flagellates or vegetative phases were evident on microscopic examination. The rumen was inoculated 2 days later with $500 \mathrm{ml}$ of pure culture of $N$. frontalis grown in vitro (Orpin, 1975). Within $48 \mathrm{~h}$, flagellates of $N$. frontalis were observed in the rumen fluid and the population density stabilized 7 to 10 days later. No other phycomycete flagellates were present, so it was assumed that all the sporangia present were of this species. The sheep was then used in experiments concerning the invasion of plant tissues suspended in nylon bags in the rumen.

Diet. The sheep were fed once daily, according to one of the following diets: (I) $800 \mathrm{~g}$ chopped hay (unidentified sward) and $200 \mathrm{~g}$ rolled oats - this was the standard diet and was used except where indicated; (2) $800 \mathrm{~g}$ perennial rye-grass (Lolium perenne L. strain S23) hay and $200 \mathrm{~g}$ rolled oats; (3) $800 \mathrm{~g}$ thrashed perennial rye-grass seed hay and $200 \mathrm{~g}$ rolled oats; (4) $800 \mathrm{~g}$ of perennial rye-grass hay; (5) $800 \mathrm{~g}$ perennial rye-grass hay and $200 \mathrm{~g}$ unthrashed whole oats; (6) I kg thrashed perennial rye-grass seed hay; or (7) young pasture harvested before inflorescence production, consisting chiefly of perennial rye grass, ad lib. Water was given ad lib.

Rumen fluid fractions. Rumen fluid, obtained by aspiration through the rumen cannula $\mathrm{I} 7$ to $20 \mathrm{~h}$ after feeding, was filtered through one layer of muslin; the filtrate was designated fresh rumen fluid (FRF). Part of this fraction was autoclaved (II ${ }^{\circ} \mathrm{C} ; 20 \mathrm{~min}$ ). The remainder was centrifuged at $1000 \mathrm{~g}$ for $15 \mathrm{~min}$ to remove the protozoa, large bacteria, flagellates and plant debris. The supernatant was then centrifuged at $38000 \mathrm{~g}$ for $\mathrm{I} h$ at $4{ }^{\circ} \mathrm{C}$ to sediment the bacteria and small particles; the clear supernatant was designated centrifuged rumen fluid (CRF). This was autoclaved $\left(115^{\circ} \mathrm{C} ; 20 \mathrm{~min}\right.$ ) to give sterile CRF. Reduced CRF was prepared by aseptic addition of $5 \mathrm{ml}$ sterile $2 \%(\mathrm{w} / \mathrm{v})$ L-cysteine hydrochloride (neutralized immediately before use with I M-NaOH) to each $100 \mathrm{ml}$ sterile CRF.

Isolation of the 'inducer' fraction from oats. The methods of Orpin (1974) were employed to obtain a fraction stimulatory to sporogenesis in $N$. frontalis. This fraction was extracted with 3 vols peroxide-free diethyl ether; the ether extract was evaporated to small volume and taken up in acetone. The final extract contained material from $\mathrm{Io} g$ dry wt oats $\mathrm{ml}^{-1}$, and was stored under $\mathrm{N}_{2}$ at $-20^{\circ} \mathrm{C}$. This extract was used as the 'inducer' throughout, except where indicated.

Sources of plant material. Pennisetum longistylum Hort. (=P. villosum, R.Br.) was from Thomson and Morgan Ltd, Ipswich, Suffolk, and grown in garden soil outdoors. Barley (Hordeum distichon) plants were supplied by Mr Hansen, Agricultural Research Council Plant Breeding Institute, Trumpington, Cambridge. Other material was obtained from within the grounds of the laboratories.

Incubation of samples of plant material in vivo. Samples of plant material were placed in nylon mesh bags (maximum mesh size $46 \mu \mathrm{m}$ ) and inserted through the cannula into the rumen of a defaunated sheep containing $N$. frontalis as the sole detectable fungal flagellate. Each bag was restrained by about $230 \mathrm{~mm}$ of nylon string, the end of which protruded through the cannula and by which the bag and contents were recovered at the end of the experiment. The bags were placed in the rumen $2 \mathrm{~h}$ before the sheep was fed, and removed I $9 \mathrm{~h}$ after feeding. After removal, the bags were washed with $50 \mathrm{ml}$ reduced CRF at $39^{\circ} \mathrm{C}$, opened, and the material retained in the bag was washed (at $39^{\circ} \mathrm{C}$ ) on the mesh with reduced CRF until the filtrate was clear. Care was taken to minimize exposure to air. The material remaining on the mesh was suspended in $10 \mathrm{ml}$ reduced $\mathrm{CRF}$ at $39^{\circ} \mathrm{C}$, centri- 
fuged at $100 \mathrm{~g}$ for $5 \mathrm{~min}$ at room temperature, and the sediment was resuspended in $2 \mathrm{ml}$ reduced $\mathrm{CRF}$ at $39^{\circ} \mathrm{C}$.

Estimation of degree of invasion of plant material by $N$. frontalis. Mature plant material was washed in $0.9 \%(\mathrm{w} / \mathrm{v}) \mathrm{NaCl}$ to free it from foreign material and separated into the following fractions: leaf tissue, including the leaf stem or, in the case of the members of the Gramineae, the leaf sheaths; flower heads including buds or, in members of the Gramineae, the seed heads; stem; and roots. Each tissue was cut into lengths of about I cm, placed in nylon bags and inserted through the cannula into the rumen. After removal from the rumen, the bags were washed as described above and the remaining plant material was resuspended in reduced CRF. The suspension was added to inducer extracted from IOO mg dry wt oats, previously dried under $\mathrm{N}_{2}$ on the bottom of a $12.5 \times \mathrm{I} \cdot 3 \mathrm{~cm}$ test tube. A sample (0.0I $\mathrm{ml}$ ) was removed, and the number of flagellates present was determined. After $30 \mathrm{~min}$ incubation at $39^{\circ} \mathrm{C}$, the number of flagellates present in a second sample $(0.01 \mathrm{ml})$ was determined. The difference between these figures gave the number of flagellates released from the sporangia in the sample. As far as could be ascertained microscopically, 100\% maturation of sporangia occurred, provided care was taken to maintain the preparation conditions as near to $39{ }^{\circ} \mathrm{C}$ as possible and to minimize exposure to oxygen. The plant material wa sedimented by centrifuging ( $100 \mathrm{~g} ; 5 \mathrm{~min}$ ), washed twice with distilled water, and dried at $60{ }^{\circ} \mathrm{C}$ to constant weight. The number of flagellates produced per $g$ plant tissue was then calculated. Not all of the sporangia on each different substrate were of the same size after the same period of incubation; therefore measurement of flagellate production could not be used to determine the number of sporangia attached. It did, however, provide a measure of the relative growth on each type of tissue.

Preparation of ${ }^{14} \mathrm{C}$-labelled barley awns. A head of barley was enclosed in a cylinder of Perspex (50 mm diam.) 3 days after anthesis. Sodium $\left[{ }^{14} \mathrm{C}\right]$ bicarbonate (ro $\mu \mathrm{Ci}$ ) was placed on filter paper in a side-arm, and the container was sealed and placed in a plant growth chamber similar to that of Walker (1965). Citric acid $(0.2 \mathrm{ml})$ was injected through a rubber septum into the side-arm to liberate ${ }^{14} \mathrm{CO}_{2}$ into the container. After $\mathrm{I} h$ the container was flushed for $15 \mathrm{~min}$ with unlabelled $\mathrm{CO}_{2}$, and the effluent gases were passed through two wash-bottles containing $3 \mathrm{M}-\mathrm{KOH}$. The head of barley was then allowed to photosynthesize with unlabelled $\mathrm{CO}_{2}$ for $30 \mathrm{~min}$, after which it was cut from the plant and removed from the Perspex container. The awns and attached lemmas were removed and stored at $4{ }^{\circ} \mathrm{C}$ if required within $24 \mathrm{~h}$, or at $-20^{\circ} \mathrm{C}$ for longer periods.

Uptake of ${ }^{14} \mathrm{C}$ by $N$. frontalis attached to barley awns. ${ }^{14} \mathrm{C}$-Labelled awns and the attached lemmas were placed in a nylon mesh bag and suspended in the rumen as previously described. When the bags were removed from the rumen, the awns and lemmas were removed and washed three times by dipping into and agitating with sterile CRF. The awns were then gently homogenized in sterile CRF in a Potter glass homogenizer; this removed many of the sporangia without extensive homogenization of the awn. The fibrous plant material was separated by filtering through a $6 \mathrm{~mm}$ pad of cotton wool placed in the stem of a $38 \mathrm{~mm}$ diam. glass funnel. The sporangia were sedimented by centrifuging (I000 $\mathrm{g} ; 5 \mathrm{~min}$ ) and washed free of small plant particles by repeated centrifuging under these conditions in $0.9 \%(\mathrm{w} / \mathrm{v}) \mathrm{NaCl}$. However, they were still contaminated by starch particles, and these were removed by digestion with amyloglucosidase from Rhizopus sp. (Sigma) in $0.2 \mathrm{M}-$ acetate buffer $\mathrm{pH} 4.8$ for $5 \mathrm{~min}$ at $39^{\circ} \mathrm{C}$. The sporangia were washed free of reaction products by centrifuging three times in $0.9 \%(\mathrm{w} / \mathrm{v}) \mathrm{NaCl}$, resuspended in $2 \mathrm{ml} 0.9 \%(\mathrm{w} / \mathrm{v})$ $\mathrm{NaCl}$ and ruptured in an MSE $\mathrm{I} 60 \mathrm{~W}$ ultrasonic disintegrator. The radioactivity in three O.I $\mathrm{ml}$ samples of the disintegrated material was determined using a Nuclear Chicago 
Unilux I I scintillation counter. Controls were similar samples obtained from the incubation of labelled plant material in a rumen free of phycomycetes and subjected to the same procedure.

The radioactivity in the awns was determined, after homogenizing them in $0.9 \%(\mathrm{w} / \mathrm{v})$ $\mathrm{NaCl}$ using an Ultra-turrax homogenizer $\left(2 \mathrm{~min}\right.$ at $\left.0^{\circ} \mathrm{C}\right)$, by counting $1.0 \mathrm{ml}$ samples of the homogenate.

Release of flagellates. The maturation and release of zoospores from the vegetative $N$. frontalis growth on the plant material was followed microscopically using the techniques of Orpin (1975).

Assessment of dry matter digestibility of dietary forage. The method of Hartley, Jones \& Fenton (1974) was used.

\section{RESULTS}

\section{Growth of $N$. frontalis on plant material in the rumen}

After $2 \mathrm{I} h$ incubation in a nylon mesh bag in the rumen, most of the tissue of leaves of Trifolium repens had been metabolized by the rumen organisms, but some, chiefly the petioles, remained. Microscopic examination revealed that attached to some of the plant material were what appeared to be sporangia (Fig. I) similar in appearance to those of $N$. frontalis. Incubation of infected tissues with inducer on a heated microscope slide (Orpin, 1975) showed that the sporangia differentiated internally with the subsequent release of $N$. frontalis flagellates, confirming that the sporagia were of this species. Examination of the residues of leaves from other mature plants incubated in the rumen under the same conditions revealed the occasional attachment of similar sporangia (Table I). There was wide variation amongst the species tested, but amongst the Gramineae results were consistent. When different tissues of wheat (Triticale aestivum), Pennisetum longistylum, barley (Hordeum distichon), Lolium perenne, Medicago sativa and Trifolium repens were tested, the association of $N$. frontalis was principally with the tissue associated with the inflorescences in the leguminous plants, especially the bracts. In the graminaceous plants, the awns, lemmas, paleas and, in Pennisetum longistylum, the involucral bracts were invaded. Results for Lolium perenne and Trifolium repens are given in Table 2. Microscopic examination of some infected tissue of Medicago sativa revealed that the hyphae of the vegetative stage of $N$. frontalis penetrated the plant material (Fig. 2) and staining with Janus green showed the ramification of fungal tissue within the plant cells.

\section{Invasion of plant barley awns by $N$. frontalis flagellates}

Microsopical examination of barley awns in the presence of $N$. frontalis flagellates in filtered rumen fluid $30 \mathrm{~min}$ after induction of sporogenesis showed that the flagellates were attracted to broken tissue and to the stomata, where no evidence of tissue damage was visible. These regions also exhibited strong attractions to rumen bacteria, for dense swarms of bacteria accumulated there within $5 \mathrm{~min}$ of incubation. After $\mathrm{I} \mathrm{h}$ incubation under these conditions, the awn tissue was removed; one piece was washed twice with reduced CRF and stained with Lugol's iodine. The attached $N$. frontalis spores (probably now at the germling stage) were stained chestnut-brown (Fig. $3 a, b, c$ ). No flagella were evident on these cells. Attachment of the flagellates to the plant tissue was principally at damaged regions, the lateral spikes and at the stomata. Another piece of tissue was incubated for a further $23 \mathrm{~h}$ in $N$. frontalis culture medium; sp orangia and rhizoids developed and after $24 \mathrm{~h}$ the sporangia had average dimensions of $48 \times 36 \mu \mathrm{m}$ (Fig. $3 d$ ).

The penetration of the plant tissue by the rhizoids could be a means of anchorage for 
Table I. Flagellate production following incubation in vitro of different plant species invaded by $N$. frontalis

Plant species

Trifolium repens $\mathrm{L}$.

T. pratense L.

Medicago sativa $\mathrm{L}$.

Lotus corniculatus $\mathrm{L}$.

Lolium perenne $\mathrm{L}$.

Lolium multiflorum Lam.

Dactylis glomerata L.

Festuca ovina agg.

Festuca rubra L.

Pennisetum longistylum Hort.
$\mathrm{IO}^{-4} \times$ No. of flagellates

(g dry wt tissue) $^{-1}$

Results show the average of three experiments.

Table 2. Invasion of Lolium perenne L. (perennial rye-grass) and

Trifolium repens $L$. (white clover) tissues by $N$. frontalis

$\begin{array}{lcc}\text { Tissue } & \overbrace{\text { Lolium perenne }}^{\mathrm{IO}^{-4} \times \mathrm{No} \text { of flagellates }(\mathrm{g} \text { dry wt tissue) })^{-1}} \\ \text { Roots } & 2 \cdot 0 & 3 \cdot 4 \\ \text { Stem } & 8 \cdot 2 & 14 \cdot 2 \\ \text { Leaves } & 42 \cdot 3 & 37 \cdot 6 \\ \text { Inflorescence } & \mathrm{I} 560 & 806 \\ \text { Seed-head } & 908 & 420\end{array}$

Results show the average of three experiments.

Table 3. Distribution of ${ }^{14} \mathrm{C}$ after growth of $N$. frontalis on

${ }^{14} \mathrm{C}$-labelled barley awns incubated in the rumen

Fraction

I. Awns before incubation

$10^{-4} \times$ Radioactivity (c.p.m.)*

2. Awns and $N$. frontalis growth, after incubation

$176 \cdot 5$

$102 \cdot 3$

3. Radioactivity lost in rumen ( $\mathrm{I}-2)$

4. Sporangia

5. Control fraction (as 4, but no N. frontalis growth)

6. Radioactivity in sporangia $(4-5)$
$74 \cdot 2$

I $6 \cdot 7$

I 9

$14 \cdot 8$

${ }^{*}$ Radioactivity per mg dry wt of material (fractions $\mathrm{I}, 2$ and 3 ), or radioactivity removed from each $\mathrm{mg}$ dry wt of awn after incubation (fractions 4,5 and 6 ). Results show the average of three experiments.

the organism while it utilized carbon sources in the rumen fluid for growth and energy; alternatively, in addition to acting as a physical anchorage, the rhizoids could be using the plant material as a carbon and energy source and acting as a saprophyte. To resolve this, ${ }^{14} \mathrm{C}$-labelled awns of barley were placed in the rumen in a nylon bag and, after incubation, were removed and washed. The sporangia were separated and assayed for ${ }^{14} \mathrm{C}$ content. The results (Table 3 ) demonstrate that $N$. frontalis, in its vegetative stage, used the barley awns as a nutrient source; this is supported by the less refractile appearance of bracts of lucerne in the region of the $N$. frontalis growth (Fig. 2). 

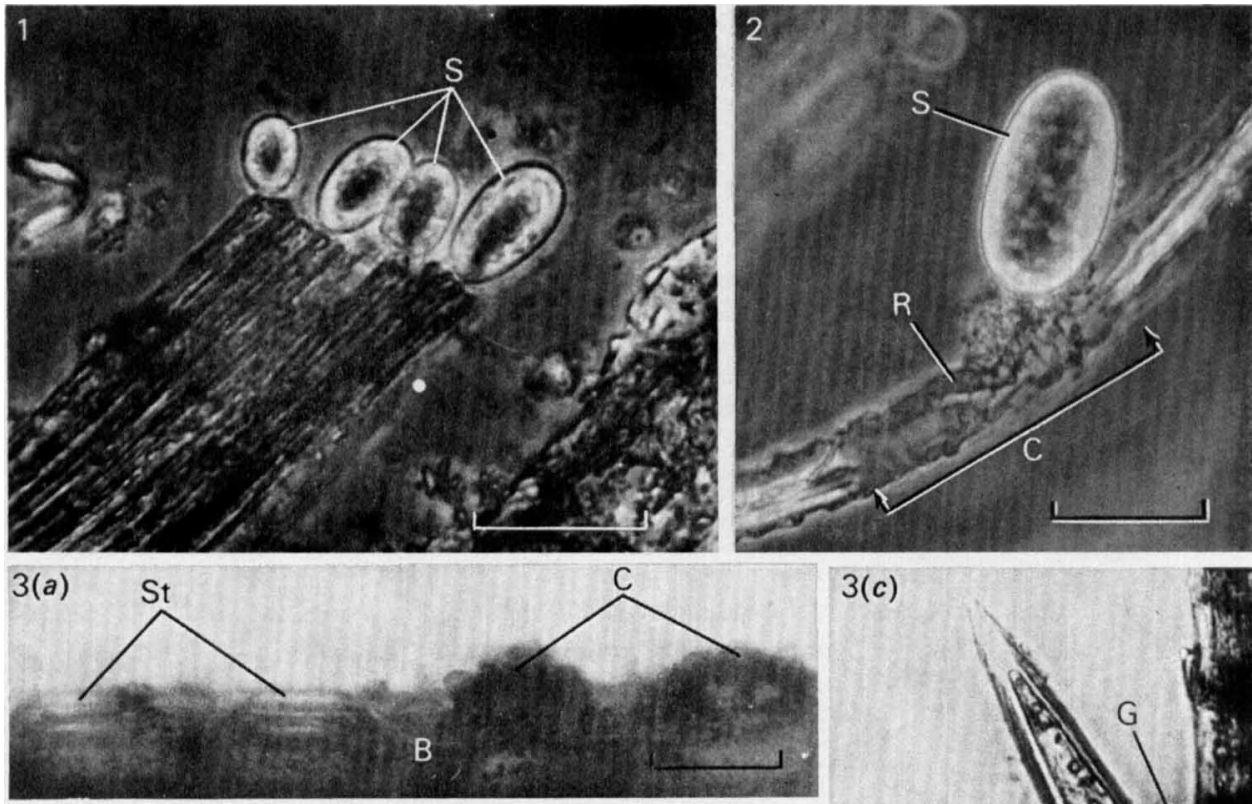

3(c)
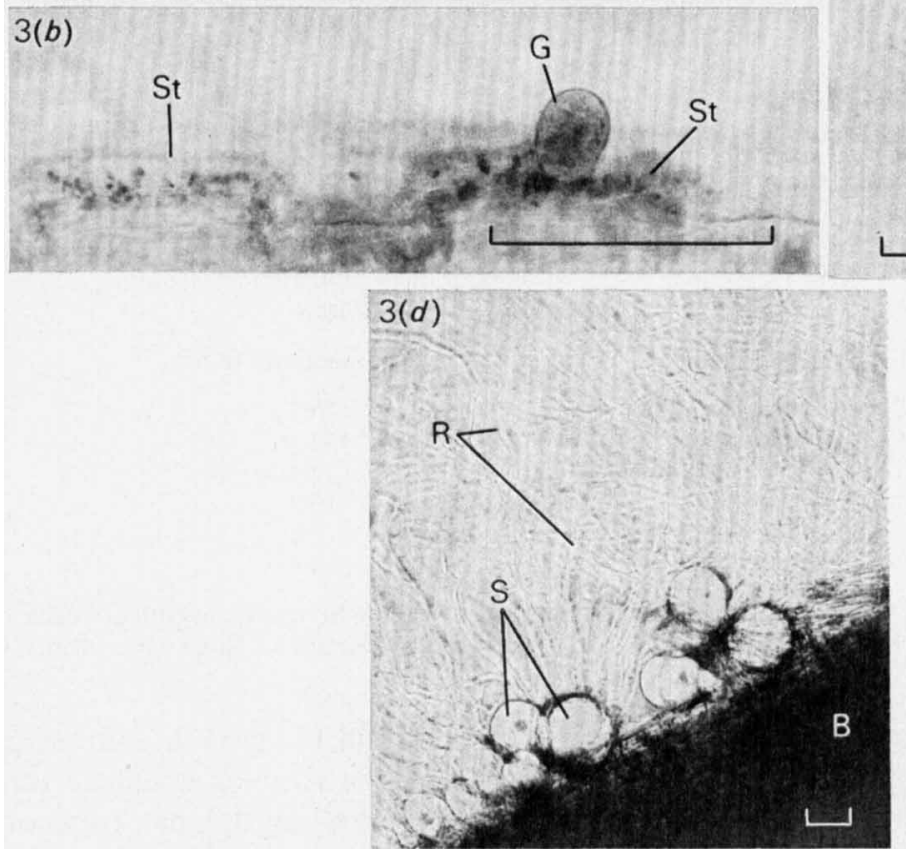

Fig. I. Residue of tissue of Trifolium repens L. (white clover) showing attached sporangia, after incubation in the rumen for $2 \mathrm{I} \mathrm{h}$. S, sporangium. Bar marker represents $100 \mu \mathrm{m}$.

Fig. 2. Vegetative phase of $N$. frontalis attached to bract of lucerne (Medicago sativa L.) bud: S, sporangium; R, rhizoid; C, area of reduced refractivity of bract. Bar marker represents $50 \mu \mathrm{m}$.

Fig. 3. Invasion of a barley awn by $N$. frontalis in vitro. (a) Surface of awn incubated in rumen fluid, containing $N$. frontalis as the only phycomycete flagellate, in the presence of inducer for $\mathrm{x} h$, washed with reduced CRF and stained with Lugol's iodine, showing clumps of $N$. frontalis at the stomata. (b) Lateral view of stoma occupied by a single $N$. frontalis germling; note the absence of flagella. (c) Neocallimastix frontalis germlings attached to spikes on side of awn. (d) Awn incubated as in (a), then incubated for $23 \mathrm{~h}$ in $N$. frontalis culture medium, showing clumps of mature sporangia and rhizoids formed in medium. G, Neocallimastix frontalis germling; S, sporangium; $\mathrm{St}$, stoma; $\mathrm{R}$, rhizoid; C, clump of $N$. frontalis germlings; B, barley awn. Bar markers represent $50 \mu \mathrm{m}$. 


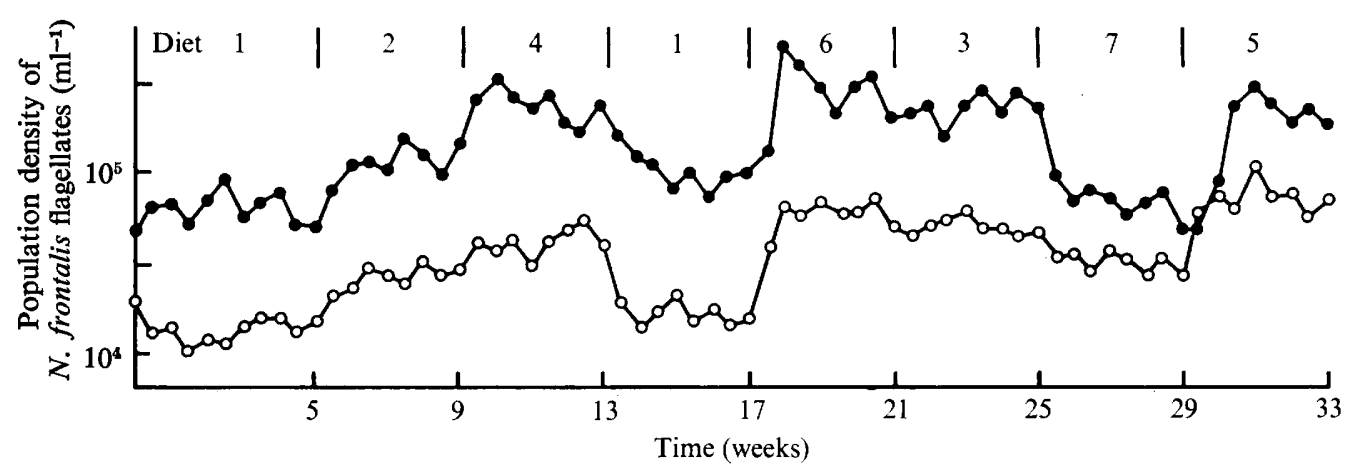

Fig. 4. Population density of $N$. frontalis in the rumen fluid of two sheep $(\bigcirc$, sheep C257; 9 , sheep C393) on various diets. Vertical lines indicate changes of diet. Samples of rumen fluid were taken $23 \mathrm{~h}$ after feeding (or at 9.00 a.m. on diet 7) and filtered through one layer of muslin. The filtered rumen fluid $(2 \mathrm{ml})$ was incubated at $39^{\circ} \mathrm{C}$ under $\mathrm{CO}_{2}$ with inducer from I $\mathrm{g}$ dry wt oats, and the $N$. frontalis flagellate population density was determined after $30 \mathrm{~min}$.

\section{The effect of dietary changes on population density of $N$. frontalis}

In the various diets, grass was supplied at different ages of maturity, and therefore contained different levels of inducer and of tissue susceptible to invasion by $N$. frontalis. In each diet the level of inducer present was sufficient for the maturation and release of flagellates from all of the sporangia as shown by microscopic examination of the rumen fluid I $\mathrm{h}$ after feeding. The proportion of tissues favoured for invasion by $N$. frontalis in each diet could not be assessed but they were essentially absent from diets $I, 2$ and 7 and high in diets 3,5 and 6 . The apparent dry matter digestibilities of the diets were: diet $1,62.4 \%$; $2,68.8 \% ; 3,56.2 \% ; 4,70.5 \% ; 5,70 \cdot 8 \% ; 6,57 \cdot 3 \%$; and $7,78.2 \%$. The results (Fig. 4) indicate that diets with a high content of seed-heads, either from perennial rye-grass or oat husks, sustained a higher population density of $N$. frontalis, despite the lower digestibility of the perennial rye-grass seed hay.

\section{DISCUSSION}

Plant material, besides triggering sporogenesis of $N$. frontalis in the rumen (Orpin, 1975), may also be used as a substratum for growth of the vegetative stage of the organism. The organism can also utilize soluble carbon sources for growth, as vegetative forms of it occur free in the rumen fluid (Orpin, 1975), and it can grow in vitro in the absence of plant tissue. The organism may therefore be only partially saprophytic in the rumen.

Neocallimastix frontalis was only rarely attached to food particles within filtered rumen contents, and it was not possible to determine whether or not the sporangia present in unfiltered rumen fluid were attached to food particles. The apparent lack of association of the vegetative stage of $N$. frontalis with food particles in filtered rumen samples may be due to the physical fracture of the sporangium from the rhizoids penetrating the food material either during filtration or during mastication by the host animal.

Growth on food particles within the rumen occurs principally on the parts of the plant for which $N$. frontalis has a pronounced affinity: the structures surrounding the inflorescences. These tissues normally comprise only a very small part of the diet, and, in sheep on pasture, only at certain times of the year. Therefore in a microscopic examination of rumen fluid the chances of finding infected tissues of this type would be low.

Although $N$. frontalis invades the tissues surrounding the flowers and seeds of plants, 
these tissues are not essential to maintain populations in the rumen, as a diet consisting of perennial rye-grass hay, harvested before the flowering stage, maintained a population density only $10 \%$ less than in the same sheep on a diet of thrashed perennial rye-grass seed hay, rich in inflorescence tissue. Diets rich in seed-heads (diets 3,5 and 6) did provide increased population densities even though the digestibility of this material was less than that of the control diets (diets 2 and 4). Whether the increased $N$. frontalis population density was caused directly by the greater quantity of inflorescence tissue in the diet, or indirectly by the effect of the diet on other rumen inhabitants which may affect $N$. frontalis, could not be resolved.

Since flagellates of $N$. frontalis show a preference for invading specific plant tissues particularly in the region of damaged tissue and the stomata (on barley awns), the flagellates are probably responding chemotactically to material leaking from this particular type of tissue. The mechanism whereby plant tissue selection occurs and the nature of the dietary component responsible for stimulating sporogenesis in $N$. frontalis is currently under investigation.

I thank Mr Hansen of the Agricultural Research Council Plant Breeding Institute for the supply of barley plants; Dr E. Bate-Smith and Dr J. West for helpful botanical discussions, Dr P. Kemp for cannulating the sheep, Mrs D. Catterall and Mr A. Letcher for technical assistance, and Mr C. S. Orpin for supplying thrashed rye-grass seed hay and perennial rye-grass hay.

\section{REFERENCES}

BRAUNE, R. (1913). Untersuchungen über die im Wiederkäuermagen vorkommenden Protozoen. Archiv für Protistenkunde 32, II I-I 70.

Das GuPTA, M. (1935). Preliminary observations on the protozoan fauna of the India goat, Capra hirens Linn. Archiv für Protistenkunde 85, $153-172$.

EADIE, J. M. (1962). The development of rumen microbial populations in lambs and calves under various conditions of management. Journal of General Microbiology 29, 563-578.

Hartuey, R. D., Jones, E. L. \& Fenton, J. S. (I974). Prediction of the digestibility of forages by treatment of their cell walls with cellulolytic enzymes. Journal of the Science of Food and Agriculture 25, 947-954.

ORPIN, C. G. (1974). The rumen flagellate Callimastix frontalis: does sequestration occur? Journal of General Microbiology 84, 395-398.

ORPIN, C. G. (1975). Studies on the rumen flagellate Neocallimastix frontalis. Journal of General Microbiology 91, 249-262.

ORPIN, C. G. (1977). The occurrence of chitin in the cell walls of the rumen organisms Neocallimastix frontalis, Piromonas communis and Sphaeromonas communis. Journal of General Microbiology 99 (in the Press).

Sparrow, F. K., JR (1960). Aquatic Phycomycetes, 2nd edn. Ann Arbor: University of Michigan Press.

WALKER, D. A. (1965). Correlation between photosynthetic activity and membrane integrity in isolated pea chloroplasts. Plant Physiology, Lancaster 40, I I57-II6I.

WARNER, A. C. I. (1966). Diurnal changes in the concentrations of micro-organisms in the rumens of sheep fed limited diets once daily. Journal of General Microbiology 45, 213-235. 